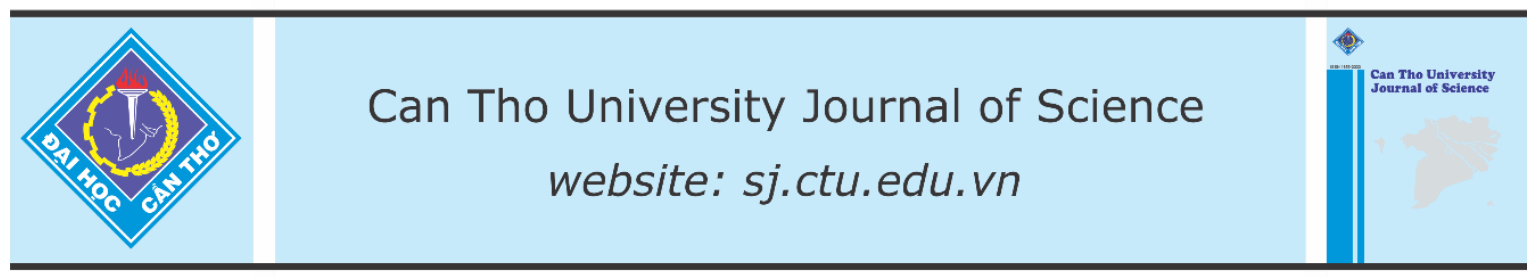

DOI: 10.22144/ctu.jen.2021.031

\title{
Antimicrobial activity of herbal extracts against Vibrio spp. bacteria isolated from white feces syndrome on white leg shrimp (Litopenaeus vannamei) in some provinces in the mekong delta
}

\author{
Truong Minh $\mathrm{Ut}^{1}$, Dao Thi Tu Uyen ${ }^{2 *}$ and Tu Thanh Dung ${ }^{2}$ \\ ${ }^{1}$ PhD student course 2016, College of Aquaculture and Fisheries, Can Tho University, Viet Nam \\ ${ }^{2}$ College of Aquaculture and Fisheries, Can Tho University, Viet Nam \\ *Correspondence: Dao Thi Tu Uyen (email: uyendao22060208@gmail.com)
}

\section{Article info.}

Received 05 Mar 2021

Revised 30 Jun 2021

Accepted 19 Jul 2021

\section{Keywords}

Antimicrobial activity, herbal extracts, white leg shrimp, white feces syndrome, Vibrio spp.

\begin{abstract}
The study was conducted to determine the antibacterial activity of three herbal extracts: guava (Psidium guajava), leafflower (Phyllanthus urinaria L), beach daisy (Wedelia biflora (L.) DC ) against Vibrio spp. isolated from white feces syndrome infected shrimp in some provinces in the Mekong Delta. The antibacterial activity of the three herbal extracts was evaluated by the well diffusion method, Minimum Inhibitory Concentration (MIC) and Minimum Bactericidal Concentration (MBC). The results indicated that there were 102 isolates in total of 378 shrimp samples which were clarified into 7 groups. Among these group, Vibrio alginolyticus group were the most abundant species with the percentage of $50 \%$, followed by Vibrio cholerae group with the percentage of 17.7\%. The herbal extracts of P. guajava and P. urinaria L showed a broad - spectrum antibacterial activity against ten isolates which were selected for MIC and MBC test. The extract of P. urinaria $L$ had the strongest antibacterial activity against $V$. harveyi $C M 3 H P A 2$ and $V$. alginolyticus CM3IB2 (MIC of $0.2 \mathrm{mg} / \mathrm{ml}, \mathrm{MBC}$ of $0.39 \mathrm{mg} / \mathrm{ml}$ ). The obtained results indicated that the herbal extract of $P$. urinaria $L$ will be a good candidate for reducing opportunistic pathogens Vibrio spp. abundant in gastrointestinal tract of shrimp.
\end{abstract}

\section{INTRODUCTION}

The Mekong Delta is the most productive area for both brackish and freshwater aquacultures in Viet Nam with high potential development. White leg shrimp (Liptopennaeus vannamei) is a type of shrimp that is widely cultivated in Viet Nam and also in some countries of Southern Asia as a source of rich nutrient food. The more intensive farming shrimps are grown, the more disease outbreaks occur. To improve production, farmers try to increase stocking density; therefore, it leads to disease outbreak easily. Aquatic animal diseases can be caused by bacteria, parasites, viruses, and fungi (FAO, 2018).

The white feces syndrome (WFS) which refers to the presence of a floating white fecal string in ponds rearing shrimp (Penaeus monodon \& $L$. vannamei) has caused significant economic damage in the cultured shrimp industry in China, Indonesia, Malaysia, Thailand, Viet Nam, and other countries in Southeast Asia (Mires \& Board, 2010). The syndrome is found to be associated with the opportunistic pathogens Vibrio spp in combination with other possible unknown pathogens (Aranguren et al., 2019). 
The growth of several bacterial diseases was initially controlled by the use of antibiotics. It increases the risks of antibiotic residues in shrimp tissues and shrimp products. It is pointed out that the antimicrobial resistant agents of the Vibrio species isolated from the shrimps farming is high (Jeyasanta et al., 2017). In that case, herbal extracts gradually become the priority as good alternative prevention for aquatic diseases due to its natural product availability.

There is a possibility for developing new antiviral drugs against white spot syndrome virus (WSSV) infection from $P$. guajava (Velmurugan et al., 2012). Other studies have proved that Phyllanthus urinaria $L$ has pharmacological effect such as hepatoprotective (Hau et al., 2009), anticancer (Huang et al., 2006) based on that it includes flavonoids, tannins, and other benzenoid constituents (Liu et al., 1999). Several medical plants used as shrimp feed supplement include bael fruit (Aegle marmelos), garlic (Allium sativum), Indian birthwort (Aristolochia indica), Indian lilac (Azadirachta indica), golden shower tree (Cassia fistula), madagasca periwinkle (Catharanthus roseus), turmeric (Curcuma longa) (Balasubramanian et al., 2007). Therefore, this study was conducted to evaluate the antimicrobial activity of Psidium guajava L., Phyllanthus urinaria L. and Wedelia biflora (L.) DC. for reducing opportunistic pathogens Vibrio spp. in the gastrointestinal tract and improving disease resistance of shrimp with highly promising to the aquaculture industry.

\section{METHODOLOGY}

\subsection{Sample collection}

Shrimp samples were collected from 63 ponds of farms in Dam Doi, Cai Nuoc, Phu Tan districts Ca Mau province, Thanh Phu district - Ben Tre province, My Xuyen, Vinh Chau districts - Soc Trang province. From each pond, 3 diseased shrimps (the presence of gross signs such as reduced feeding, retarded growth, floating white fecal string in ponds and in the feeding tray, etc.) and 3 healthy shrimps were collected. The shrimp samples were collected at shrimp farm. Shrimp samples were put into plastic bags with oxygen supplied and transported to the laboratory.

\subsection{Bacteria isolation and storage}

First of all, shrimp samples were put on clean trays for observing and recorded the external and internal clinical signs. Secondly, the inoculating loop was used to get samples of bacterial from the intes- tine, hepatopancreatic of shrimp specimens and then streaking onto the Thiosulfate Citrate Bile Salts Sucrose agar (Merck) plate. After that, the plates were incubated for 24 hours at $28^{\circ} \mathrm{C}$. The dominant bacterial colonies were subcultured onto Trypto-casein Soy Agar supplemented with 1.5\% $\mathrm{NaCl}(\mathrm{TSA}+1.5 \% \mathrm{NaCl})$ media and incubated for 24 hours at $28^{\circ} \mathrm{C}$. A pure well-isolated colony was selected and incubated into Brain Heart Infusion Broth supplemented with $1.5 \% \mathrm{NaCl}$ (BHIB+1.5\% $\mathrm{NaCl}$ ) for 24 hours at $28^{\circ} \mathrm{C}$. These served as stock cultures by mixing with glycerol $(20 \%)$. The stock cultures were stored in the lowest compartment of the freezer $\left(-80^{\circ} \mathrm{C}\right)$ (Lightner, 1996).

\subsection{Bacterial identification}

Bacterial identification was done by primary tests including (Gram staining, motility, oxidase, and catalase). The commercially available kit API 20E (BioMerieux, France) was used for determining the biochemical profiles of isolates. The 16S rRNA gene of these isolates was sequenced and compared to GenBank database - NCBI BLAST for species identification. According to information on clinical signs recorded from farmers in different locations, 22 isolates with typical clinical signs were randomly selected for identification.

\subsection{Herbal extraction}

P. guajava, $P$. urinaria $L$ and $W$. biflora (L.) $D C$ extracts were supplied by Vibo Company. Firstly, the collected of whole plant samples were cleaned to get rid of dust particles, then were cut into small pieces and ground into fine powder by an electrical blender. The powder samples were macerated in methanol $96 \%$ (the ratio 1:10) for 3 days at room temperature. After that, the extracted solutions were filtered through Whatman no. 1 filter paper and released the solvent by a rotary vacuum evaporator at $40^{\circ} \mathrm{C}$.

\subsection{Antibacterial activity}

Ten isolates selected randomly from 22 identified isolates were used to evaluate the antibacterial activities of herbal extracts by the standard well diffusion method (Magaldi et al., 2004). A cotton swab was dipped into the bacterial suspension of approximately $1 \times 10^{8} \mathrm{CFU} / \mathrm{mL}$ tube and streaked on TSA $+1.5 \% \mathrm{NaCl}$ discs. The wells were made by a $6 \mathrm{~mm}$ diameter standard sterile cork. The herbal extracts were diluted with dimethyl sulfoxide (DMSO) solution to reach the final concentration at 100,50 and $25 \mathrm{mg} / \mathrm{mL}$. These wells were filled up with $50 \mu \mathrm{L}$ of herbal extracts. The plates were in- 
cubated at $28^{\circ} \mathrm{C}$ for 24 hours. DMSO was used as a negative control. Antibacterial activity was determined by measuring the diameter of the inhibition zone (Oonmetta-aree et al., 2006).

\subsection{Minimal inhibitory concentration (MIC)}

Two herbal extracts (P. guajava, $P$. urinaria $L$ ) were selected for the Minimum Inhibitory Concentration (MIC) test. In the broth dilution method, 3 $\mathrm{mL}$ of herbal extract in the $\mathrm{BHIB}+1.5 \% \mathrm{NaCl}$ solutions were prepared by two fold dilutions from 25 to $25 / 1024(0.02) \mathrm{mg} / \mathrm{mL}$ (10 times) in the test tubes. The standardized bacterial suspension of 10 isolates $\left(1 \times 10^{6} \mathrm{CFU} / \mathrm{mL}\right)$ was inoculated in the series of broth dilution at $28^{\circ} \mathrm{C}$ for 24 hours. MIC was determined as the herbal extracts that completely inhibit the growth of bacteria on the lowest concentration (Oonmetta-aree et al., 2006).

\subsection{Minimum bactericidal concentration (MBC)}

Thirty $\mu \mathrm{l}$ of ten isolates from MIC asays were streaked onto TCBS plate, and counted colonies after 24-hour incubation for $28^{\circ} \mathrm{C}$. MBC was determined as the lowest concentration of the herbal extracts in which no bacteria growth (Oonmettaaree et al., 2006).

Table 1. Colonial morphology characteristics of 7 isolated groups on TCBS and TSA + medium

\section{CODE TCBS medium $\quad$ TSA medium}

A1 Green colonies, typical 2-3 mm diameter, round, Light yellow, round, smooth colonies, 1- 2mm, opaque, green, or bluish colonies, convex

A2 Green colonies, small, 1-2mm

A3 Green colonies, 3-4 $\mathrm{mm}$ in diameter

A4 Blue green colonies

A5 Green colonies, round

B1 Large, flat, smooth yellow colonies, $2-3 \mathrm{~mm}$ in diameter

B2 Large yellow colonies

\subsection{Data analysis}

The average value, percentage and standard deviation were analyzed by using Microsoft Office Excel 2010 software and the 16S-RNA gene sequenced results of isolates were compared to GenBank database - NCBI Blast.

\section{RESULTS AND DISCUSSIONS}

\subsection{Bacterial isolation and identification}

A total of 63 shrimp ponds including 39 farms in Ca Mau province (located in Dam Doi, Cai Nuoc, Phu Tan districts), 10 farms in Soc Trang province (located in My Xuyen, Vinh Chau districts), and 14 farms in Ben Tre province (located in Thanh Phu district) from October 2019 to August 2020. The clinical signs included an empty and discontinuous gut, a paler and white hepatopancreas, retarded growth, reduced feeding, some ponds showed white feces strings in the feeding trays according to information obtained from the farmers. There were 102 isolates in total 378 shrimp samples collected from shrimp ponds. According to phenotypic characteristics, colony morphology on TCBS and $\mathrm{TSA}+1.5 \% \mathrm{NaCl}$ media, these isolated strains were clarified into 7 groups (Table 1).

Five dominant groups B2 (50\%), B1 (17.7\%), A4 (10.8\%), A2 (6.9\%) and A1 (5.8\%) (Table 2) consisting of 22 isolates were chosen for bacterial identification.

Table 2. The results of sampling and proportion of Vibrio spp. groups isolated in white leg shrimp

\begin{tabular}{lcrrrrrrrr}
\hline \multirow{2}{*}{ Location } & No. shrimp & \multicolumn{7}{c}{ No. isolates from white leg shrimp } & \multirow{2}{*}{ Sampling time } \\
\cline { 3 - 10 } & sampling & A1 & A2 & A3 & A4 & A5 & B1 & B2 & \\
\hline Phu Tan $^{1}$ & 42 & 1 & 0 & 0 & 6 & 3 & 1 & 5 & $10 / 2019$ \\
Dam Doi $^{1}$ & 102 & 0 & 2 & 1 & 2 & 0 & 0 & 13 & $12 / 2019$ \\
Cai Nuoc $^{1}$ & 90 & 2 & 2 & 1 & 1 & 0 & 6 & 16 & $06 / 2020$ \\
Thanh Phu $^{2}$ & 84 & 3 & 1 & 0 & 2 & 1 & 6 & 9 & $07 / 2020$ \\
Vinh Chau, My Xuyen $^{3}$ & 60 & 0 & 2 & 3 & 0 & 0 & 5 & 8 & $08 / 2020$ \\
\hline Total & 378 & 6 & 7 & 5 & 11 & 4 & 18 & 51 & \\
Percentage (\%) & & 5.8 & 6.9 & 4.9 & 10.8 & 3.9 & 17.7 & 50 & \\
\hline
\end{tabular}

Notes: 1. Ca Mau province; 2. Ben Tre province; 3. Soc Trang province. 
Table 3. Morphological, physiological and biochemical characteristics of 22 isolates belonging to 5 groups

\begin{tabular}{|c|c|c|c|c|c|}
\hline & $\begin{array}{c}\mathbf{A 1} \\
(\mathrm{n}=2)\end{array}$ & $\begin{array}{c}\mathbf{A 2} \\
(\mathrm{n}=2)\end{array}$ & $\begin{array}{c}\mathbf{A 4} \\
(n=4)\end{array}$ & $\begin{array}{c}\text { B1 } \\
(n=6)\end{array}$ & $\begin{array}{c}\text { B2 } \\
(\mathrm{n}=8)\end{array}$ \\
\hline Gram - staining & - & - & - & - & - \\
\hline Morphology & $\begin{array}{l}\text { curved-rod } \\
\text { (comma) }\end{array}$ & $\begin{array}{l}\text { curved-rod } \\
\text { (comma) }\end{array}$ & $\begin{array}{l}\text { curved-rod } \\
\text { (comma) }\end{array}$ & $\begin{array}{l}\text { curved-rod } \\
\text { (comma) }\end{array}$ & $\begin{array}{l}\text { curved-rod } \\
\text { (comma) }\end{array}$ \\
\hline TCBS & Green colony & Green colony & Green colony & $\begin{array}{l}\text { Yellow } \\
\text { colony }\end{array}$ & $\begin{array}{l}\text { Yellow } \\
\text { colony }\end{array}$ \\
\hline Motility & + & + & + & + & + \\
\hline Catalase & + & + & + & + & + \\
\hline Oxidase & + & + & + & + & + \\
\hline Facultative anaerobes & + & + & + & + & + \\
\hline Facultative aerobes & + & + & + & + & + \\
\hline$\beta$ - galactosidase & + & + & + & + & + \\
\hline Arginine & - & - & + & - & - \\
\hline Lysine & + & + & - & + & + \\
\hline Ornithine & + & + & - & + & - \\
\hline Citrate & + & + & + & + & + \\
\hline $\mathrm{H} 2 \mathrm{~S}$ & - & - & - & - & - \\
\hline Urease & - & - & - & - & - \\
\hline Tryptophan deaminase & + & + & + & + & + \\
\hline Indole & + & + & + & + & + \\
\hline Voges - Proskauer & + & + & + & + & + \\
\hline Gelatinase & + & + & - & + & - \\
\hline Glucose & + & + & + & + & + \\
\hline Mannose & + & + & + & + & + \\
\hline Inositol & - & - & - & - & - \\
\hline Sorbitol & - & - & - & - & - \\
\hline Rhamnose & - & - & - & - & - \\
\hline Sucrose & + & - & - & + & + \\
\hline Melibiose & - & - & - & - & - \\
\hline Amygdalin & + & + & + & - & + \\
\hline Arabinose & + & - & - & - & + \\
\hline
\end{tabular}

The results indicated that five dominant groups were identified as $V$. parahaemolyticus (A1), $V$. haveryi (A2), V. vulnificus (A4), V. cholerae (B1) and $V$. alginolyticus (B2) by secondary kit test API 20E (Table 3). The 16s - rRNA gene sequence of five dominant groups (A1, A2, A4, B1, B2) was also submitted to GenBank database with an accession no. NR119058.1, KT982474.1, NR117906.1, NR044853.1, NR118258.1 and the similarity between its 16S rRNA gene sequence and other isolates in the GenBank database is $99.78 \%, 100 \%$, $99.5 \%, 100 \%, 99.85 \%$, respectively.

Another study in Thailand also showed large amounts of Vibrio bacteria including V. vulnificus, $V$. fluvialis, V. parahaemolyticus, V. alginolyticus, $V$. damselae, $V$. minicus and $V$. cholerae at different proportions of $80,44,26,20,28,8$ and $6 \%$ in haemolymph and intestine with two - fold higher than that of healthy ones, respectively (Somboon et al., 2012). Interestingly, $V$. parahaemolyticus, $V$. vulnificus, $V$. cholerae and $V$. anguillarum have been recovered in the L. vannamei infected white feces syndrome in Jawa Tengah province, Indonesia (Jayadi et al., 2016). Supono et al. (2019) showed that $V$. vulnificus, $V$. parahaemolyticus and $V$. alginolyticus were suspected of triggering white feces syndrome in East Lampung Regency, Indonesia. In addition, five species including $V$. parahaemolyticus, $V$. fluvialis, $V$. mimicus and $V$. alginolyticus had been reported from infected white feces syndrome of L. vannamei shrimps in Andhra Pradesh (Mastan, 2015).

Presently, the causative agents of white feces syndrome in shrimp remains unknown. This syndrome 
has been associated with a microsporidian - EHP (Enterocytozoon hepatopenaei) (Rajendran et al., 2016). In addition, EHP also was proposed as the causative agent in P. monodon (Ha et al., 2013) and L. vannamei (Tang et al., 2016). However, it was failed to illustrate white feces syndrome in the experiment infected EHP (Tangprasittipap et al., 2013). Woraprayote et al. (2020) reported that Vibrio abundances increase in shrimp haemolymph and intestine has been also related to white feces syndrome.

Among these groups in this study, $V$. alginolyticus (B2 group) was the most abundant species with the percentage of $50 \%$ and $V$. cholerae (B1 group) was the second high abundant species with the percentage of $17.7 \%$. Similarly, V. alginolyticus and $V$. fluvialis have been recorded as the major pathogen contribute the occurrence of white feces syndrome in grow-out ponds of $P$. monodon in Sri Lanka (Sandaruwan Kumara \& Hettiarachchi, 2017). Moreover, Cao et al. (2015) found that $V$.
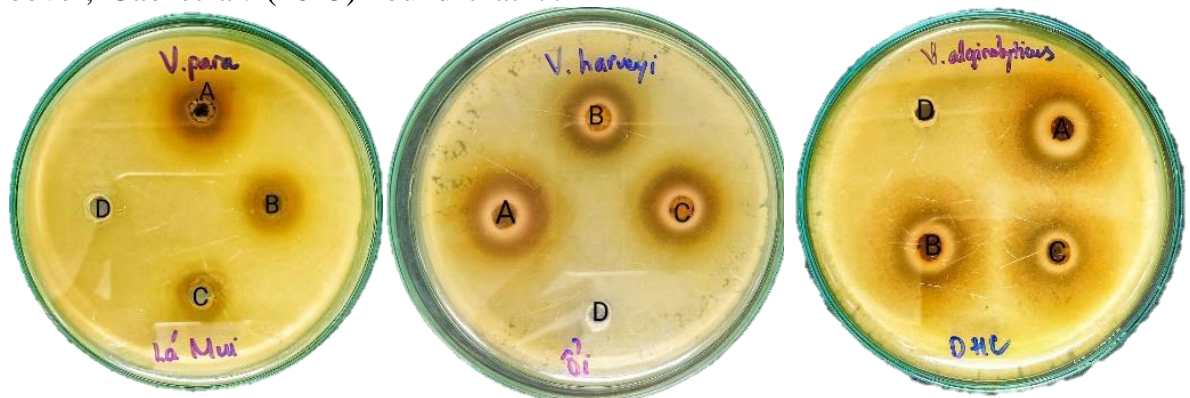

Figure 3. Antimicrobial activity of tested herbal extracts in Vibrio spp. bacteria cholerae isolate was a pathogen for white feces syndrome on L. vannamei in China.

In general, based on the percentage of isolated bacterial groups, total of 10 isolates including 5 isolates of $V$. alginolyticus with the highest percentage (50\%); 2 isolates of $V$. cholerae $(17.7 \%)$; 1 isolate of $V$. vulnificus (10.8\%), 1 isolate of $V$. haveryi (6.9\%), 1 isolate of $V$. parahaemolyticus $(5.8 \%)$ were chosen for screening of antimicrobial activity of different herbal extracts.

\subsection{Screening of antimicrobial activity of different herbal extracts on ten isolated Vibrio spp. bacteria}

The antibacterial activity of herbal extracts using standard well diffusion method (Magaldi et al., 2004) with the results shown in Figure 3 and Table 4. The results indicated that three tested herbal extracts exhibited different antibacterial activities against ten isolates.
(A) $100 \mathrm{mg} / \mathrm{mL}$, (B)
(B) $50 \mathrm{mg} / \mathrm{mL}$,
(C) $25 \mathrm{mg} / \mathrm{mL}$,
(D) $\mathrm{DMSO}$

Noticeably, among three tested herbal extracts, P. urinaria $\mathrm{L}$ showed the highest antibacterial activity against all ten isolates with the growth inhibition zone fluctuated from 12.7 to $24.85 \mathrm{~mm}$. In detail, the results pointed that the highest antibacterial activity against V. alginolyticus CM3IB2 with the inhibition zone was $24.85 \mathrm{~mm}, 23.4 \mathrm{~mm}, 20.45 \mathrm{~mm}$ at three concentrations.

Besides, DMSO played a role as the negative control of all tests showed the zone at $0 \mathrm{~mm}$ (Table 4).

In this study, $P$. guajava showed the intermediate antibacterial activity with the highest inhibition zone were $22.95,20.7,17.7 \mathrm{~mm}$ on $V$. alginolyticus CM3IB2 (Table 4). The extract of $W$. biflora $(L$.) $D C$ showed the lowest antibacterial activity than the other two herbal extracts with the highest inhi- bition zone were $16.45,14.35,11.45 \mathrm{~mm}$ on $V$. parahaemolyticus BTIA1 and the lowest inhibition zone on V. cholerae CM1HPB1 (Table 4).

In addition, mangrove leaf extract (Rhizophora apiculata) had the best effect on $V$. parahaemolyticus with the inhibition zone of $5.61 \mathrm{~mm}$ at 700 $\mathrm{mg} / \mathrm{L}$ (Supono et al., 2019). According to Widowati et al. (2018), microalgae Dunaliella salina and Tetraselmis chui were applied as biocontrol agents for 21 days showing a decrease of bacteria amount and its capable against Vibrio. Moreover, supplementation of hen egg white lysozome (HEWL) at $0.125 \mathrm{~g} / \mathrm{kg}$ into feed was demonstrated as an effective method not only to avoid antibiotic treatment in aquaculture but also stimulated resistance to Vibrio infection as well as white feces syndrome (Woraprayote et al., 2020). 
Table 4. Mean of inhibition zone diameter of three herbal extracts in ten isolates

\begin{tabular}{|c|c|c|c|c|c|c|c|c|c|}
\hline \multirow{3}{*}{ Isolates } & \multicolumn{9}{|c|}{ Mean of inhibition zone diameter (mm) } \\
\hline & \multicolumn{2}{|c|}{ P. urinaria $L$} & \multicolumn{3}{|c|}{ P. guajava } & \multicolumn{4}{|c|}{ W. biflora (L.) DC } \\
\hline & $\begin{array}{r}100 \\
\mathrm{mg} / \mathrm{mL}\end{array}$ & $50 \mathrm{mg} / \mathrm{mL}$ & $25 \mathrm{mg} / \mathrm{mL}$ & $\begin{array}{r}100 \\
\mathrm{mg} / \mathrm{mL} \\
\end{array}$ & $50 \mathrm{mg} / \mathrm{mL}$ & $25 \mathrm{mg} / \mathrm{mL}$ & $\begin{array}{r}100 \\
\mathrm{mg} / \mathrm{mL} \\
\end{array}$ & $50 \mathrm{mg} / \mathrm{mL}$ & $25 \mathrm{mg} / \mathrm{mL}$ \\
\hline $\begin{array}{l}\text { V.parahaemolyticus } \\
\text { BTIA1 }\end{array}$ & $18.9 \pm 0.4$ & $17.25 \pm 0.25$ & $15.75 \pm 0.45$ & $18.3 \pm 0.9$ & $15.8 \pm 0.2$ & $14.2 \pm 0.2$ & $16.45 \pm 0.75$ & $14.35 \pm 0.75$ & $11.45 \pm 0.05$ \\
\hline $\begin{array}{l}\text { V. harveyi } \\
\text { CM3HPA2 }\end{array}$ & $24.65 \pm 0.45$ & $23.9 \pm 0.3$ & $22.65 \pm 0.45$ & $22.7 \pm 0.4$ & $21.8 \pm 0.4$ & $20.6 \pm 0.6$ & $16.2 \pm 0.2$ & $13.85 \pm 0.45$ & $11.45 \pm 0.25$ \\
\hline $\begin{array}{l}\text { V. vulnificus } \\
\text { CM2HPA4 }\end{array}$ & $17.15 \pm 0.15$ & $15.1 \pm 0.3$ & $13.45 \pm 0.25$ & $11.85 \pm 0.55$ & $10.9 \pm 0.4$ & $9 \pm 0$ & $12.15 \pm 0.15$ & $11 \pm 0.3$ & $7.05 \pm 0.05$ \\
\hline $\begin{array}{l}\text { V. cholerae } \\
\text { CM3HPTB1 }\end{array}$ & $19.7 \pm 0.3$ & $18.15 \pm 0.15$ & $16.75 \pm 0.35$ & $17.35 \pm 0.25$ & $16.2 \pm 0.2$ & $13.75 \pm 0.25$ & $14.9 \pm 0.3$ & $13.4 \pm 0.2$ & $11.7 \pm 0.3$ \\
\hline $\begin{array}{l}\text { V. cholerae } \\
\text { CM1HPB1 }\end{array}$ & $17.95 \pm 0.35$ & $16.4 \pm 0.2$ & $15.15 \pm 0.15$ & $14.3 \pm 0.3$ & $\begin{array}{r}12.25 \pm \\
0.05\end{array}$ & $10.6 \pm 0.4$ & $9.85 \pm 0.25$ & $8.8 \pm 0.3$ & $8 \pm 0.2$ \\
\hline $\begin{array}{l}\text { V. alginolyticus } \\
\text { CM2HPB2 }\end{array}$ & $16.7 \pm 0.3$ & $15.85 \pm 0.15$ & $14 \pm 0$ & $15.4 \pm 0.2$ & $\begin{array}{r}13.15 \pm \\
0.85\end{array}$ & $11.9 \pm 0.4$ & $13.8 \pm 0.2$ & $11.6 \pm 0.4$ & $10.95 \pm 0.25$ \\
\hline $\begin{array}{l}\text { V. alginolyticus } \\
\text { STIB2 }\end{array}$ & $18.1 \pm 0.2$ & $16.65 \pm 0.15$ & $15.5 \pm 0.2$ & $17.65 \pm 0.45$ & $13.85 \pm 0.35$ & $12.6 \pm 0.4$ & $12.15 \pm 0.15$ & $11.1 \pm 0.1$ & $9.65 \pm 0.35$ \\
\hline $\begin{array}{l}\text { V. alginolyticus } \\
\text { CM2IB2 }\end{array}$ & $18.2 \pm 0.2$ & $16.2 \pm 0.6$ & $14.95 \pm 0.15$ & $15.95 \pm 0.35$ & $14.65 \pm 0.35$ & $13 \pm 0$ & $14.8 \pm 0.2$ & $13.4 \pm 0.2$ & $11.25 \pm 0.15$ \\
\hline $\begin{array}{l}\text { V.alginolyticus } \\
\text { CM3НРВ2 }\end{array}$ & $15.9 \pm 0.1$ & $14.25 \pm 0.15$ & $12.7 \pm 0.4$ & $14 \pm 0$ & $11.55 \pm 0.55$ & $10.15 \pm 0.15$ & $14.95 \pm 0.15$ & $13.4 \pm 0.6$ & $10.75 \pm 0.25$ \\
\hline $\begin{array}{l}\text { V. alginolyticus } \\
\text { CM3IB2 }\end{array}$ & $24.85 \pm 0.15$ & $23.4 \pm 0.6$ & $20.45 \pm 0.15$ & $22.95 \pm 0.15$ & $20.7 \pm 0.3$ & $17.7 \pm 0.3$ & $12.4 \pm 0.2$ & $11 \pm 0$ & $8.05 \pm 0.05$ \\
\hline
\end{tabular}

Notes: Growth inhibition zone: Resistant $\leq 9 \mathrm{~mm}$; Intermediate: $\geq 10$ - $13 \mathrm{~mm}$; Susceptible: $\geq 15$ mm (Chaweepack et al., 2015)

\subsection{Determination of Minimum Inhibitory Concentration (MIC) and Minimum Bactericidal Concentration (MBC)}

MIC and MBC were determined based on the results of the antibacterial activity test. Amongst tested herbal extracts, $P$. guajava and $P$. urinaria $L$ with higher antibacterial activity were continuously tested to determine MIC and MBC. The result is shown in Table 5.

The results indicated that the highest MIC values of $P$. urinaria $L$ extracts were defined at 0.2 $\mathrm{mg} / \mathrm{mL}$ on V.parahaemolyticus BTIA1, V. harveyi CM3HPA2, V. alginolyticus CM3IB2 and $V$. alginolyticus CM3HPB2, MBC values were $0.78,0.39$, $0.39,1.56 \mathrm{mg} / \mathrm{mL}$, respectively. In detail, the highest ratio of $\mathrm{MBC} / \mathrm{MIC}$ of $P$. urinaria $L$ extract were 2 on $V$. harveyi CM3HPA2, $V$. alginolyticus CM3IB2 while the ratio values were 4 on V.parahaemolyticus BTIAl, V. cholerae CM3HPTB1, V. cholerae CM1HPB1, V. alginolyticus STIB2, V. alginolyticus CM2IB2 and the values were 8 on the remaining isolates.

As reported by Canillac and Mourey. (2001), the ratio of $\mathrm{MBC} / \mathrm{MIC}$ is equal to or less than 4 means that the extraction considered bactericidal ability. On the other hand, this ratio is larger than 4 that shows the bacteriostatic ability. In this study, $P$. urinaria $L$ extract showed higher values of the ratio of MBC/MIC compared to P. guajava on all ten isolates with the MBC/MIC ratio values was 4 on $V$. parahaemolyticus BTIA1, $V$. harveyi CM3HPA2, V. alginolyticus CM3IB2 while it was 16 only on $V$. vulnificus CM2HPA4, and the ratio values were 8 on 6 isolates other.

Phyllanthus amarus had antibacterial activity against $V$. parahaemolyticus causing AHPND on whiteleg shrimp (L. vannamei) in both kinds of fresh plants $(250 \mathrm{mg} / \mathrm{mL})$ and dried plants $(125$ $\mathrm{mg} / \mathrm{mL}$ ) (Phuong et al., 2019). Guava leaf extract ( $P$. guajava) was proved that it had the resistance ability to 21 bacterial strains: L. monocytogenes (5 strains), $S$. aureus (4 strains), E. coli (6 strains) $S$. enteritidis (4 strains), $V$. parahaemolyticus, $B$. cereus and 5 bacteria that spoil food (Mahfuzul Hoque et al., 2007). In addition, 11 tested herbal extracts showed antibacterial activity among sixteen, $P$. guajava and $M$. charantia displayed the highest activity against Vibrio harveyi and $V$. parahaemolyticus with the MIC of $P$. guajava was found to be $0.625 \mathrm{mg} / \mathrm{mL}$, while the MIC of $M$. charantia was $1.25 \mathrm{mg} / \mathrm{mL}$ ( Direkbusarakom et al, 1998). 
Table 5. Minimum Inhibitory Concentration (MIC) and Minimum Bactericidal Concentration (MBC) of tested herbal extracts

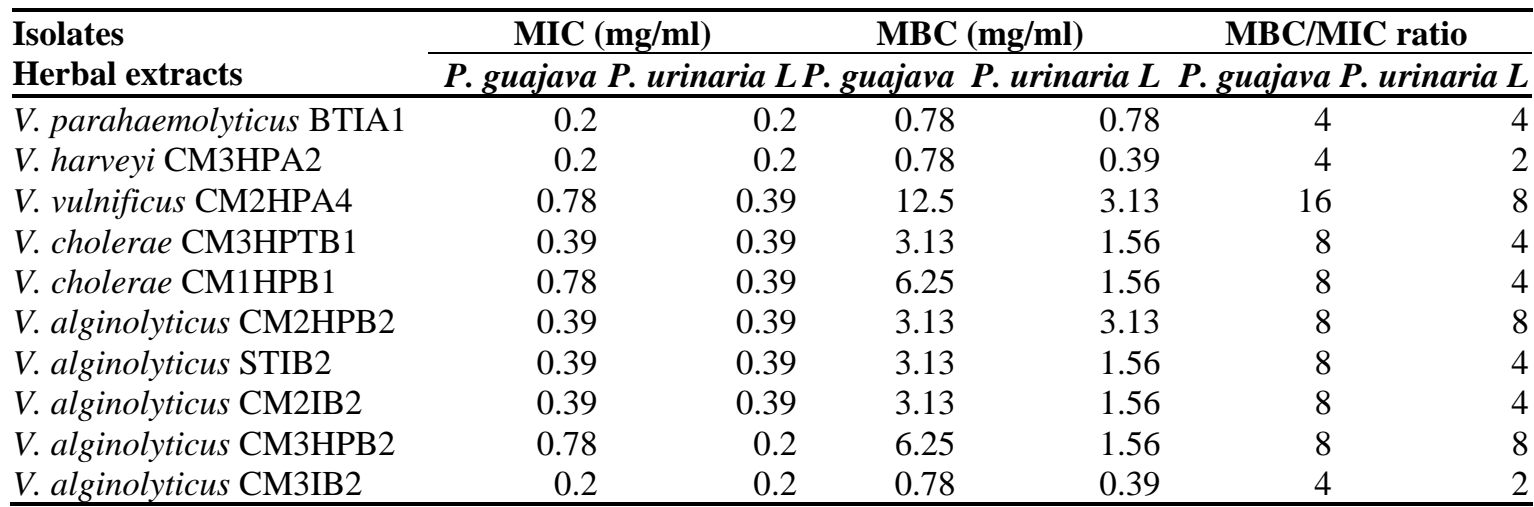

\section{CONCLUSIONS AND} RECOMMENDATIONS

\subsection{Conclusions}

There were 102 isolates in total shrimp samples which had clinical signs of white feces syndrome. Among these groups, V. alginolyticus group was the most abundant species with the percentage of $50 \%$, followed by $V$. cholerae group with a percentage of $17.7 \%$. The herbal extracts of $P$. guaja$v a, P$. urinaria $L$ showed a broad spectrum antibacterial activity against 10 isolates in diseased shrimp.

The extract of $P$. urinaria $L$ had the strongest antibacterial activity against $V$. harveyi $\mathrm{CM} 3 \mathrm{HPA} 2$ and $V$. alginolyticus CM3IB2 (MIC of $0.2 \mathrm{mg} / \mathrm{mL}$, $\mathrm{MBC}$ of $0.39 \mathrm{mg} / \mathrm{mL}$ ).

\subsection{Recommendations}

Among isolated bacterial strains, $V$. alginolyticus group was the most abundant species with a percentage of $50 \%$. It should be carried out in the challenge test for the confirmation of the possible causative agents and the recurrence of white feces syndrome. The herbal extracts of $P$. guajava, $P$. urinaria $L$ should be further studied in in vivo studes.

\section{REFERENCES}

Aranguren, L. F., Mai, H., Pichardo, O., Hanggono, B., \& Dhar, A. K. (2019). White feces syndrome in shrimp: Predictor of EHP? Global Aquaculture Advocate, April 29.

Balasubramanian, G., Sarathi, M., Kumar, S. R., \& Hameed, A. S. S. (2007). Screening the antiviral activity of Indian medicinal plants against white spot syndrome virus in shrimp. Aquaculture, 263(1-4), 1519. https://doi.org/10.1016/j.aquaculture.2006.09.037
Canillac, N., \& Mourey, A. (2001). Antibacterial activity of the essential oil of Picea excelsa on Listeria, Staphylococcus aureus and coliform bacteria. Food Microbiology, 18(3), 261-268. https://doi.org/10.1006/fmic.2000.0397

Cao, H., Wen, L., He, S., Lu, L., Yang, X., \& Chen, B. (2015). Vibrio cholerae: A causal agent for white feces syndrome in freshwater cultured whiteleg shrimp (Penaeus vannamei). Israeli Journal of Aquaculture-Bamidgeh, 67.

Chaweepack, T., Khomvilai, C., Chaweepack, S., \& Kamei, K. (2015). Effect of galangal (Alpinia galanga Linn.) extract on the growth rate and resistance to Vibrio harveyi and white spot diseases in Pacific white shrimp (Litopenaeus vannamei). Journal of Agricultural Science. https://doi.org/10.5539/jas.v7n9p117

FAO. (2018). The State of World Fisheries and Aquaculture 2018 - Meeting the sustainable development goals. Rome. Licence: CC BY-NC-SA 3.0 IGO.

Hau, D. K. P., Gambari, R., Wong, R. S. M., Yuen, M. C. W., Cheng, G. Y. M., Tong, C. S. W., ... \& Fong, D. W. F. (2009). Phyllanthus urinaria extract attenuates acetaminophen induced hepatotoxicity: involvement of cytochrome P450 CYP2E1. Phytomedicine, 16(8), 751-760.

Huang, S. T., Yang, R. C., Lee, P. N., Yang, S. H., Liao, S. K., Chen, T. Y., \& Pang, J. H. S. (2006). Antitumor and anti-angiogenic effects of Phyllanthus urinaria in mice bearing Lewis lung carcinoma. International Immunopharmacology, 6(6), 870-879. https://doi.org/10.1016/j.intimp.2005.12.010

Jayadi, M., Prajitno, A., \& Maftuch. (2016). The identification of Vibrio spp. bacteria from Litopenaeus vannamei infected by white feces syndrome. International Journal of ChemTech Research, 9(7), 448-452.

Jeyasanta, K. I., Lilly, T., \& Patterson, P. (2017). Prevalence of Vibrio species in the Cultured Shrimp and Their Antibiotic Resistants. Asian Journal of Applied Science and Technology, 1(8), 100-111. 
Lightner, D. V. (1996). A Handbook of Shrimp Pathology and Diagnostic Procedures for Diseases of Cultured Penaeid Shrimp. In World Aquaculture Society. https://www.bookdepository.com/Handbook-ShrimpPathology-Diagnostic-Procedures-for-DiseasesCultured-Penaeid-Shrimp-Donald-VLightner/9780962452994

Liu, K. C. S. C., Lin, M. T., Lee, S. S., Chiou, J. F., Ren, S., \& Lien, E. J. (1999). Antiviral tannins from two Phyllanthus species. Planta Medica, 65(1), 43-46. https://doi.org/10.1055/s-1999-13960

Magaldi, S., Mata-Essayag, S., Hartung De Capriles, C., Perez, C., Colella, M. T., Olaizola, C., \& Ontiveros, Y. (2004). Well diffusion for antifungal susceptibility testing. International Journal of Infectious Diseases, 8(1), 39-45. https://doi.org/10.1016/j.ijid.2003.03.002

Mahfuzul Hoque, M. D., Bari, M. L., Inatsu, Y., Juneja, V. K., \& Kawamoto, S. (2007). Antibacterial activity of Guava ( Psidium guajava L.) and Neem ( Azadirachta indica A. Juss.) extracts against foodborne pathogens and spoilage bacteria. Foodborne Pathogens and Disease, 4(4), 481-488. https://doi.org/10.1089/fpd.2007.0040

Mastan, S. A. (2015). Incidences of white feces syndrome (WFS) in farm-reared shrimp, Litopenaeus vannamei, Andhra Pradesh. Indo American Journal of Pharmaceutical Research, 5(9), 3044-3047. www.iajpr.com

Mires, D., \& Board, E. (2010). A causal agent of red leg disease in freshwater-cultured whiteleg shrimp Penaeus vannamei. The Open Access Israeli Journal of Aquaculture - Bamidgeh Providencia alcalifaciens.

Oonmetta-aree, J., Suzuki, T., Gasaluck, P., \& Eumkeb, G. (2006). Antimicrobial properties and action of galangal (Alpinia galanga Linn.) on Staphylococcus aureus. LWT - Food Science and Technology, 39(10), 1214-1220. https://doi.org/10.1016/j.lwt.2005.06.015

Phuong, T. V., Yen, H., \& Linh, N. Q. (2019). Antibacterial activity of extracts from dried and fresh herbal plant (Phyllanthus amarus) against pathogens causing acute hepatopancreatic necrosis disease (Ahpnd) in white leg shrimp (Litopenaeus vannamei) at Thua Thien Hue Province, Vietnam. Asploro Journal of Biomedical and Clinical Case Reports, 2019(3), 120.

Rajendran, K. V., Shivam, S., Praveena, P. E., Rajan, J. J. S., Kumar, T. S., Avunje, S., ... \& Vijayan, K. K. (2016). Emergence of Enterocytozoon hepatopenaei (EHP) in farmed Litopenaeus vannamei in India. Aquaculture, 454, 272-280.

Sandaruwan Kumara, K. R. P., \& Hettiarachchi, M. (2017). White faeces syndrome caused by Vibrio alginolyticus and Vibrio fluvialis in shrimp, Penaeus monodon (Fabricius 1798)-multimodal strategy to control the syndrome in Sri Lankan grow-out ponds. Asian Fisheries Science, 30(4), 245-261. https://doi.org/10.33997/j.afs.2017.30.4.003

Somboon, M., Purivirojkul, W., Limsuwan, C., \& Chuchird, N. (2012). Effect of Vibrio spp. in White Feces Infected Shrimp in Chanthaburi, Thailand. Journal of Fisheries and Environment, 36(1), 7-15. https://li01.tcithaijo.org/index.php/JFE/article/view/80769

Supono, Wardiyanto, Harpeni, E., Khotimah, A. H., \& Ningtyas, A. (2019). Identification of Vibrio sp. as cause of white feces diseases in white shrimp Penaeus vannamei and handling with herbal ingredients in east Lampung regency, Indonesia. AACL Bioflux, 12(2), 417-425.

Tang, K. F. J., Han, J. E., Aranguren, L. F., WhiteNoble, B., Schmidt, M. M., Piamsomboon, P., Risdiana, E., \& Hanggono, B. (2016). Dense populations of the microsporidian Enterocytozoon hepatopenaei (EHP) in feces of Penaeus vannamei exhibiting white feces syndrome and pathways of their transmission to healthy shrimp. Journal of Invertebrate Pathology, 140, 1-7. https://doi.org/10.1016/j.jip.2016.08.004

Tangprasittipap, A., Srisala, J., Chouwdee, S., Somboon, M., Chuchird, N., Limsuwan, C., Srisuvan, T., Flegel, T. W., \& Sritunyalucksana, K. (2013). The microsporidian Enterocytozoon hepatopenaei is not the cause of white feces syndrome in whiteleg shrimp Litopenaeus vannamei. BMC Veterinary Research, 9(1), 139.

Velmurugan, S., Michael Babu, M., J Punitha, S. M., Thanga Viji, V., \& Citarasu, T. (2012). Screening and characterization of antiviral compounds from Psidium guajava Linn. root bark against white spot syndrome virus. In Indian Journal of Natural Products and Resources, 3(2), 208-214. http://nopr.niscair.res.in/handle/123456789/14421

Widowati, I., Zainuri, M., Kusumaningrum, H. P., Maesaroh, Y., Hardivillier, Y., Leignel, V., Bourgougnon, N., \& Mouget, J. L. (2018). Identification of agents causing vibriosis in Litopenaeus vannamei shrimp culture in Kendal, Central Java, Indonesia and application of microalgae Dunaliella salina and Tetraselmis chui as bio-control agents against vibriosis. AACL Bioflux, 11(1), 101-107.

Woraprayote, W., Pumpuang, L., Tepaamorndech, S., Sritunyalucksana, K., Phromson, M., Jangsutthivorawat, W., Jeamsripong, S., \& Visessanguan, W. (2020). Suppression of white feces syndrome in Pacific white shrimp, Litopenaeus vannamei, using hen egg white lysozyme. Aquaculture, 521(January), 735025. https://doi.org/10.1016/j.aquaculture.2020.735025 